\title{
Downstream components of RhoA required for signal pathway of superoxide formation during phagocytosis of serum opsonized zymosans in macrophages
}

\author{
Jun-Sub Kim", Jae-Gyu Kim¹, Chan-Young Jeon ${ }^{1}$, \\ Ha-Young Won ${ }^{1}$, Mi-Young Moon ${ }^{1}$, Ji-Yeon Seo', \\ Jong-II Kim ${ }^{1}$, Jaebong Kim ${ }^{1}$, Jae-Yong Lee ${ }^{1}$, \\ Soo-Young Choi ${ }^{2}$, Jinseu Park', \\ Jung Han Yoon Park ${ }^{3}$, Kwon-Soo $\mathrm{Ha}^{4}$, \\ Pyeung-Hyeun $\mathrm{Kim}^{5}$ and Jae-Bong Park ${ }^{1,6}$ \\ ${ }^{1}$ Department of Biochemistry \\ College of Medicine \\ ${ }^{2}$ Department of Genetic Engineering \\ ${ }^{3}$ Department of Nutrition \\ Division of Life Science \\ Hallym University \\ Chuncheon 220-702, Korea \\ ${ }^{4}$ Department of Biochemistry \\ ${ }^{5}$ Department of Microbiology \\ College of Medicine \\ Kangwon National University \\ Chuncheon 200-701, Korea \\ ${ }^{6}$ Corresponding author: Tel, 82-33-248-2542; \\ Fax, 82-33-244-8425; E-mail, jbpark@hallym.ac.kr
}

\section{Accepted 24 October 2005}

Abbreviations: AEBSF, 4-(2-aminoethyl)benzenesulfony fluoride; DMPC, dimyristoylphosphatidyl choline; DPI, diphenyleneiodonium chloride; ERK1/2, extracellular signaling-regulated kinase 1/2; GST, glutathione S-transferase; HRP, horse-radish peroxidase; IPTG, isopropylthio- $\beta$-D-galactoside; isoluminol, 6-amino-2,3-dihydro-1,4phtalazinedione; luminol, 5-amino-2,3-dihydroxy-1,4-phtalazinedione; LY294002, 2-(4-Morpholinyl)-8-phenyl-4H-1-benzopyran-4one; MAPK, mitogen-activated protein kinase; MEK, MAP kinase kinase; MV, methylviologen; NAC, N-acetyl-L-cysteine; PA, phosphatidic acid; PI3K, phosphatidyl inositol 3-kinase; PD98059, 2'-amino-3'-methoxyflavone; SB203580, 4-(4-Fluorophenyl)-2-(4-methylsulfinylphenyl)-5-(4-pyridyl)1H-imidazole; SOD, superoxide dismutase; SOZ, serum-opsonized zytmosan

\footnotetext{
Abstract

Rac1 and Rac2 are essential for the control of oxidative burst catalyzed by NADPH oxidase. It was also documented that Rho is associated with the superoxide burst reaction during phagocytosis of serum- (SOZ) and IgG-opsonized zymosan particles
}

(IOZ). In this study, we attempted to reveal the signal pathway components in the superoxide formation regulated by Rho GTPase. Tat-C3 blocked superoxide production, suggesting that RhoA is essentially involved in superoxide formation during phagocytosis of SOZ. Conversely SOZ activated both RhoA and Rac1/2. Inhibition of RhoA-activated kinase (ROCK), an important downstream effector of RhoA, by Y27632 and myosin light chain kinase (MLCK) by ML-7 abrogated superoxide production by SOZ. Extracellular signaling-regulated kinase (ERK)1/2 and p38 mitogenactivated protein kinase (MAPK) were activated during phagocytosis of SOZ, and Tat-C3 and SB203580 reduced ERK1/2 and $\mathrm{p} 38$ MAPK activation, suggesting that RhoA and p38 MAPK may be upstream regulators of ERK1/2. Inhibition of ERK1/2, p38 MAPK, phos phatidyl inositol 3-kinase did not block translocation of RhoA to membranes, suggesting that RhoA is upstream to these kinases. Inhibition of RhoA by Tat-C3 blocked phosphorylation of $\mathrm{p} 47^{\mathrm{PHOX}}$. Taken together, RhoA, ROCK, p38MAPK, ERK1/2, and $\mathrm{p} 47^{\mathrm{PHOX}}$ may be subsequently activated, leading to activation of NADPH oxidase to produce superoxide.

Keywords: extracellular signal-regulated MAP kinases; macrophages; NADPH oxidase; P38 mitogen-activated protein kinases; rhoA GTP-binding protein; superoxides

\section{Introduction}

Phagocytosis of pathogens and apoptotic cells by macrophages triggers the immune response and is important to host defense mechanisms. Phagocytosis is performed through the receptors such as complement receptor type 3 (CR3, referred also as CD11b/CD18, Mac-1, and integrin $\alpha M \beta 2)$, Fc $\gamma$ receptors (FcyRs), and mannose receptor. CR3 recognizes the $\mathrm{C} 3 \mathrm{~b} / \mathrm{C} 3 \mathrm{bi}$ fragments coating particles like pathogens, Fc $\gamma$ Rs recognize the Fc $\gamma$ domain of immunoglobulin $G(\lg G)$, and mannose receptor recognizes mannose and fucose in the capsule or on the lipopolysaccharide of invading bacteria (Brown, 1995; Chimini and Chavrier, 2000).

Subsequently, macrophage induces the abrupt increase of superoxide formation, referred to as oxidative burst, which is mediated by NADPH oxidase. 
The phagocyte NADPH oxidase is a membraneassociated enzyme complex that generates superoxide $\left(\mathrm{O}_{2}^{-}\right)$by the one-electron reduction of oxygen, using NADPH as the electron donor (Babior, 1999). The core enzyme of NADPH oxidase is composed of five components. Among them, p22 $2^{\text {PHOX }}$ and gp91 ${ }^{\text {PHOX }}$ exist in the membranes of the secretory granular vesicles, which form a heterodimeric flavohemoprotein known as cytochrom $b_{558}$ (Rotrosen et al., 1993). The other components, $\mathrm{p} 40^{\mathrm{PHOX}}, \mathrm{p} 47^{\text {PHOX }}$, and p $67^{\text {PHOX }}$ are located in the cytosol as a complex form (Wientjes et al., 1996). p47 $7^{\text {PHOX }}$ becomes highly phosphorylated by protein kinases (Park and Babior, 1997; Park et al., 1997), and the entire cytosolic complex of $\mathrm{p} 40^{\text {PHOX }}, \mathrm{p} 47^{\text {PHOX }}$, and $\mathrm{p} 67^{\mathrm{PHOX}}$ translocates to the membrane, where it associates with cytochrome $b_{558}$ to assemble the active NADPH oxidase (Heyworth et al., 1991; Sathyamoorthy et al., 1997). In addition to the core subunits, Ras- related small GTP-binding proteins, Rac1 or Rac2 is required for the activation of NADPH oxidase (Mizuno et al., 1992; Kreck et al., 1994; Kim et al., 2001). In resting state Rac is localized in the cytoplasm in a dimeric complex with Rho GDP dissociation inhibitor (GDI), while GTP-bound Rac translocates to the membrane along with core cytosolic complex during activation (Knaus et al., 1992; Quinn et al., 1993; Bokoch, 1994).

Rho family proteins in actin dynamics are essential for the phagocytosis and engulfment (Chimini and Chavrier, 2000). It was found that Cdc42/Rac regulated the phagocytosis mediated through FcR and the subsequent superoxide formation through FcyR activation is regulated by Rac, whereas Rho regulated phagocytosis mediated through CR3 (Caron and Hall, 1998; Massol et al., 1998). Besides Rac, RhoA was reported to be also involved in the production of $\mathrm{H}_{2} \mathrm{O}_{2}$ in other cell lines such as swiss 3T3 fibroblast (Koo et al., 1999) and Rat-2 fibroblast (Lee et al., 2000), when TGF and EGF stimulated them, respectively. In addition to $\mathrm{FCR}$, the stimulation of CR3 by anti-CR3 antibody-coated particles (Serrander et al., 1999), by Staphylococcus particles with anti-CD18 antibodies (Lofgren et al., 1999), and by zymosan ingestion through CR3 (Le Cabec et al., 2000) induces superoxide production. Recently, it has been documented that Rho is essentially involved in superoxide formation during phagocytosis of opsonized zymosans (Kim et al., 2004). In this study, we elucidated the components required for signal pathway regulating superoxide formation mediated by Rho.

\section{Materials and Methods}

\section{Materials}

Zymosan A particles, FITC, BSA, isopropylthio-
$\beta$-D-galactoside (IPTG), NAD ${ }^{+}, \mathrm{GDP}$, triethanolamine/HCl, DTT, PMSF, Y-27632, 5-amino-2,3-dihydro-1,4-phtalazinedione (luminol), 6-amino-2,3-dihydro-1,4-phtalazinedione (isoluminol), 2'-amino-3'methoxyflavone (PD98059), 4-(4-fluorophenyl)-2-(4methylsulfinylphenyl)-5-(4-pyridyl) $1 \mathrm{H}$-imidazole (SB203580), 2-(4-morpholinyl)-8-phenyl-4H-1-benzopyran-4-one (LY294002), PMA, dimyristoylphosphatidyl choline (DMPC), Triton X-100, and glutathione (GSH) were purchased from Sigma chemicals. PBS without calcium or magnesium was purchased from Bio-Whittaker. Catalase, horse-radish peroxidase (HRP), and superoxide dismutase (SOD) were purchased from Roche Molecular Biochemicals. FBS, DMEM, and penicillin- streptomycin were purchased from GibcoBRL. C3bi was from Calbiochem, and IgG against zymosan was from Molecular Probe. GSH-Sepharose bead was purchased from Pharmacia. Anti-RhoA, anti-His antibodies were purchased from Santa Cruz, and antiphospho-extracellular signal-regulated kinase (ERK), -phospho-JNK, and -phospho-p38 antibodies and antip38 antibody were from Cell Signaling. Anti-p47 ${ }^{\text {PHOX }}$ antibody and pGEX-1 $1 \lambda$ T plasmid containing $\mathrm{GSH}$ S-transferase (GST)-p47 $7^{\mathrm{PHOX}}$ fused gene were kindly given from Dr. J. W. Park of Kyoungbuk National University. Tat-C3 exoenzyme was expressed in E.coli $\mathrm{DH} 5 \alpha$ and purified through $\mathrm{Ni}^{2+}$-IDA gel column (Novagen).

\section{Expression and purification of the Tat-C3}

For the preparation of Tat-C3 exoenzyme, E. coli BL21 (Pharmacia) transformed with pC3 or pTat-C3 constructs were grown overnight at $37^{\circ} \mathrm{C}$ in LB broth supplemented with $100 \mu \mathrm{g} / \mathrm{ml}$ ampicillin. The purification of the proteins was performed following the methods described in previous reports (Park et al., 2003; Kim et al., 2004).

\section{Cell culture and transduction of Tat-C3 fusion protein}

Macrophage $\mathrm{J} 774$ cell line was cultured in DMEM containing $20 \mathrm{mM}$ Hepes/NaOH ( $\mathrm{pH} 7.4), 5 \mathrm{mM}$ $\mathrm{NaHCO}_{3}, 10 \%$ FBS and antibiotics $(100 \mathrm{U} / \mathrm{ml}$ streptomycin and $100 \mathrm{U} / \mathrm{ml}$ penicillin) at $37^{\circ} \mathrm{C}$ in $5 \% \mathrm{CO}_{2}$. For the transduction of Tat-C3, macrophage cells were grown to confluence on 6-well plate for 4-6 h. And then culture medium was replaced with $1 \mathrm{ml}$ of fresh solution without FBS. J774 cells were treated with various concentrations of Tat-C3 for $30 \mathrm{~min}$, and then were performed the assays for the phagocytosis and association of particles. For the assay of RhoA modification by Tat-C3, the cell lysates pretreated with Tat-C3 were run on SDS- PAGE and RhoA protein was analyzed by Western blot by using anti-RhoA antibody. 


\section{Preparation of FITC-zymosan}

Zymosan A particles were labeled with FITC without addition of gelatin (Gelfand et al., 1976). The zymosan particles were then pelleted by centrifugation, washed more than 7 times, and resuspended in PBS (adjusted to $5 \times 10^{8}$ zymosan particles $/ \mathrm{ml}$ ). Aliquots were stored at $-70^{\circ} \mathrm{C}$ and thawed immediately before use (Gelfand et al., 1976). Zymosans were opsonized with $1 \mathrm{mg} / \mathrm{ml}$ mouse serum (SOZ), C3bi, and IgG (Allen and Aderem, 1996). C3b in the serum was found to rapidly fix onto zymosan, and about $80 \%$ of the $\mathrm{C} 3 \mathrm{~b}$ to be converted to $\mathrm{C} 3 \mathrm{bi}$ when zymosan was opsonized with fresh FBS at $37^{\circ} \mathrm{C}$ (Newmans and Mikus, 1985).

\section{Assay of phagocytosis and association of zymosan on the surface of macrophages}

Cells were plated onto $35-\mathrm{mm}$ dishes at a density of $2 \times 10^{5}$ cells and grown overnight, and the cells were incubated in DMEM media without FBS for 16 $\mathrm{h}$ at $37^{\circ} \mathrm{C}$ in $\mathrm{CO}_{2}$ incubator. Cells were incubated for 30 min with $5 \times 10^{5}$ of FITC-conjugated zymosan particles previously resuspended in fresh mouse serum to $1 / 4$ dilution. The cells were washed with PBS three times to clear the unbound zymosan particles and detached from dishes with $2 \mathrm{ml}$ PBS. The phagocytosis was assayed by measuring the intensity of FITC engulfed into the cells. FITC was excited at $490 \mathrm{~nm}$ and the emission fluorescence of it was immediately measured at $520 \mathrm{~nm}$ by fluorescence spectrophotometer (Kontron SFM25). The fluorescence of adherent FITC-zymosan on the surface of the cells was quenched by addition of crystal violet to $10 \mu \mathrm{M}$ of final concentration (Hed et al., 1987). The association of FITC-zymosans on the cell surface was evaluated by subtracting the value of net translocated fluorescence intensity from total fluorescence intensity (Kim et al., 2003).

\section{Determination of superoxide}

For the measurement of extracellular superoxide, J774 cells $\left(2 \times 10^{3}\right)$ were harvested and washed 3 times with PBS. And then the cells were resuspended in $1 \mathrm{ml}$ of modified Krebs-Ringer buffer (KRG: $120 \mathrm{mM} \mathrm{NaCl}, 5 \mathrm{mM} \mathrm{KCl}, 1.7 \mathrm{mM} \mathrm{KH}_{2} \mathrm{PO}_{4}$, $8.3 \mathrm{mM} \mathrm{Na}_{2} \mathrm{HPO}_{4}, 10 \mathrm{mM}$ glucose, $1 \mathrm{mM} \mathrm{CaCl}_{2}$, and $1.5 \mathrm{mM} \mathrm{MgCl} 2$ ) containing $4 \mathrm{U} / \mathrm{ml} \mathrm{HRP}$ and $0.05 \mathrm{mM}$ isoluminol (Dahlgren and Karlsson, 1999). For the measurement of intracellular superoxide, J774 cells $\left(2 \times 10^{3}\right)$ were harvested and washed 3 times with PBS, and resuspended in $1 \mathrm{ml}$ of KRG buffer containing $50 \mathrm{U} / \mathrm{ml} \mathrm{SOD}, 2000 \mathrm{U} / \mathrm{ml}$ catalase and 0.05 mM luminol (Dahlgren and Karlsson, 1999). In both cases, the reaction of superoxide formation was started by addition of opsonized zymosan particles $\left(2 \times 10^{4}\right)$, and the subsequent chemiluminiscence was measured by Luminometer (Lumat LB 9507, EG \& G, Berthold, Germany). To examine the effect of Tat-C3 on the formation of superoxide, purified TatC3 $(10 \mu \mathrm{g} / \mathrm{ml})$ was pretreated to the $\mathrm{J} 774$ cell for 30 min at $37^{\circ} \mathrm{C}$ (Kim et al., 2003).

\section{Expression and purification of GST-RhoA and GST-Rac1 fusion proteins, and measurement of GTP-binding to the fusion proteins, and of super- oxide formation induced by GST-RhoA-GTP}

For the preparation of GST-RhoA and GST-Rac1, pGEX4T1-RhoA, and pGEX4T1-Rac1 plasmids were transformed into $E$. coli $\mathrm{DH} 5 \alpha$ and grown. And then the expressions of proteins were induced by the addition of $0.1 \mathrm{mM}$ IPTG as the preparation of TatC3. GST-RhoA and GST-Rac1 proteins were purified using affinity of GSH-Sepharose beads to GSTfusion proteins. The proteins were eluted with $5 \mathrm{mM}$ $\mathrm{GSH}$ and the GSH was eluted out by dialysis against a buffer (50 mM Hepes, pH 7.4, $1 \mathrm{mM}$ DTT, $2 \mu \mathrm{g} / \mathrm{ml}$ aprotinin and $2 \mu \mathrm{g} / \mathrm{ml}$ leupeptin). For the binding of GTP to the fusion proteins, $1 \mu \mathrm{g}$ GST-RhoA and GST-Rac1 were incubated with $0.1 \mu \mathrm{M}\left[\gamma^{35} \mathrm{~S}\right] \mathrm{GTP}$ in $50 \mu \mathrm{l}$ of GTP-binding buffer (10 mM Hepes, $\mathrm{pH}$ 7.4, $0.5 \mu \mathrm{M} \mathrm{MgCl}_{2}, 1 \mathrm{mM} \mathrm{DTT}$, and $\left.1 \mathrm{mM} \mathrm{DMPC}\right)$ containing $30 \mu \mathrm{g}$ BSA as a carrier protein for $10 \mathrm{~min}$ at $30^{\circ} \mathrm{C}$ following Kikuchi's method with a little modification (Kikuchi et al., 1988). The GTP-binding activities were stopped by addition of $1 \mathrm{ml}$ of ice-cold stop buffer (20 mM Hepes, pH 7.4, $100 \mathrm{mM} \mathrm{NaCl}$, and $25 \mathrm{mM} \mathrm{MgCl}_{2}$ ). The reaction mixtures were filtered immediately on a BA85 membrane (Schleicher \& Schuell) and the membranes were washed 5 times with $1 \mathrm{ml}$ of cold stop buffer. Radioactivity of dried membranes in $5 \mathrm{ml}$ cocktail (Beckman, Ready Safe) was measured by using a liquid scintillation counter (Beckman LS5000TD). For the measurement of superoxide formation induced by RhoA in vitro, various concentration of GST-RhoA was incubated in the presence of $0.1 \mathrm{mM}$ GDP or GTP in $1 \mathrm{ml} \mathrm{KRG}$ buffer containing $50 \mu \mathrm{M}$ luminol with cell lysates which were prepared by sonication. The reaction of superoxide formation was started by addition of $0.1 \mathrm{mM} \mathrm{NADPH}$, and the subsequent chemiluminiscence was measured using Luminometer.

\section{Translocation of RhoA and $\mathrm{p} 47^{\mathrm{PHOX}}$ proteins}

J774 macrophages $\left(2 \times 10^{6}\right.$ cells $)$ were treated with $50 \mu \mathrm{M}$ LY294002, $50 \mu \mathrm{M}$ PD98059, $30 \mu \mathrm{M}$ SB203580, and $10 \mu \mathrm{g} / \mathrm{ml}$ Tat-C3 for $30 \mathrm{~min}$ at $37^{\circ} \mathrm{C}$. The cells were harvested and lysed with a sonication in $50 \mu \mathrm{l}$ lysis buffer (20 mM Hepes, pH 7.4, 150 mM NaF, 2 
$\mathrm{mM} \mathrm{NaVO}{ }_{4}, 20 \mathrm{mM} \mathrm{Na} \mathrm{P}_{2} \mathrm{O}_{7}, 50 \mu \mathrm{g} / \mathrm{ml}$ PMSF, 2 $\mu \mathrm{g} / \mathrm{ml}$ aprotinine, $2 \mu \mathrm{g} / \mathrm{ml}$ leupeptin, $2 \mu \mathrm{g} / \mathrm{ml}$ pepstatin A, and $0.05 \%$ Triton-X 100) (Hippenstiel et al., 1998). The cell membranes were harvested by a table-top ultracentrifuge for $30 \mathrm{~min}$ at $100,000 \times \mathrm{g}$, $4^{\circ} \mathrm{C}$, and the membranes were resuspended in $50 \mu \mathrm{l}$ the lysis buffer. For the measurement of translocation of $\mathrm{p} 47^{\mathrm{PHOX}}$, both the membrane and the supernatant solution were run on $14 \%$ SDS-PAGE, and Western blot was performed by using anti-p47 ${ }^{\text {PHOX }}$ antibody.

\section{GST pull-down assay for activated RhoA, Rac1, and Rac2}

Briefly, a total of $2 \times 10^{6}$ cells cultured in $100-\mathrm{mm}$ plates were washed in ice-cold PBS and harvested. The cells were lysed in lysis buffer $(50 \mathrm{mM}$ Tris- $\mathrm{HCl}$, $\mathrm{pH} 7.2,1 \%$ Triton $\mathrm{X}-100,0.1 \%$ SDS, $0.5 \%$ sodium deoxycholate, $500 \mathrm{mM} \mathrm{NaCl}, 10 \mathrm{mM} \mathrm{MgCl}, 5 \mu \mathrm{g} / \mathrm{ml}$ each of leupeptin and aprotinin, and $1 \mathrm{mM}$ PMSF). After centrifugation $\left(15,000 \mathrm{rpm}, 15 \mathrm{~min}, 4^{\circ} \mathrm{C}\right)$, aliquots of the supernatant were added to GST-Rho binding domain of Rhotekin (GST-RBD), or GSTGTPase binding domain of p21-activated kinase-1 (PAK-1) (GST-PBD), which was previously incubated for $1 \mathrm{~h}$ with $50 \mu \mathrm{g}$ of GSH-Sepharose beads for GST-fusion protein or Ni-NTA His-Bind resins for His-fusion protein. The beads were incubated with cell lysates and washed, and the proteins on the beads were run on SDS-PAGE. RhoA, Rac1, and
Rac2 were determined by Western blotting using each antibody (Ren et al., 2000; Kim et al., 2004).

\section{Scanning electron microscopy (SEM)}

Control J774 cells were collected from the Petri dishes, centrifuged $(1,000 \times g$ for $5 \mathrm{~min})$ and fixed in suspension with $2.5 \%$ glutaraldehyde in $0.1 \mathrm{M}$ cacodylate buffer $(\mathrm{pH} \mathrm{7.4)}$ at room temperature for $20 \mathrm{~min}$. After washing twice with the same buffer, the cells were seeded on glass coverslips coated with fibrinogen for $1 \mathrm{~h}$ at room temperature. Cells were challenged with $\mathrm{SOZ}$ or IOZ on glass coverslips for $30 \mathrm{~min}$ and also fixed with $2.5 \%$ glutaradehyde for $20 \mathrm{~min}$ at room temperature and washed twice with the $0.1 \mathrm{M}$ cacodylate buffer. All samples were post-fixed in $1 \%$ osmium tetroxide for $30 \mathrm{~min}$ at room temperature, dehydrated through graded ethanols, critically dried in $\mathrm{CO}_{2}$ and gold coated by sputtering. The samples were examined with a Cambridge 360 scanning electron microscope.

\section{Expression and purification of GST-p47 $7^{\mathrm{PHOX}}$, and kinase assay of recombinant GST-p47 $7^{\text {PHOX }}$ fusion protein}

Recombinant GST- p47 ${ }^{\text {PHOX }}$ fusion protein as a substrate for kinase was prepared following the procedure described by Park and Babior (Park and Babior, 1997). Briefly, E. coli transformed with pGEX$1 \lambda T$ containing an insert of $p 47^{\text {PHOX }}$ cDNA were grown in the presence of $1 \mathrm{mM}$ IPTG and lysed. The
A

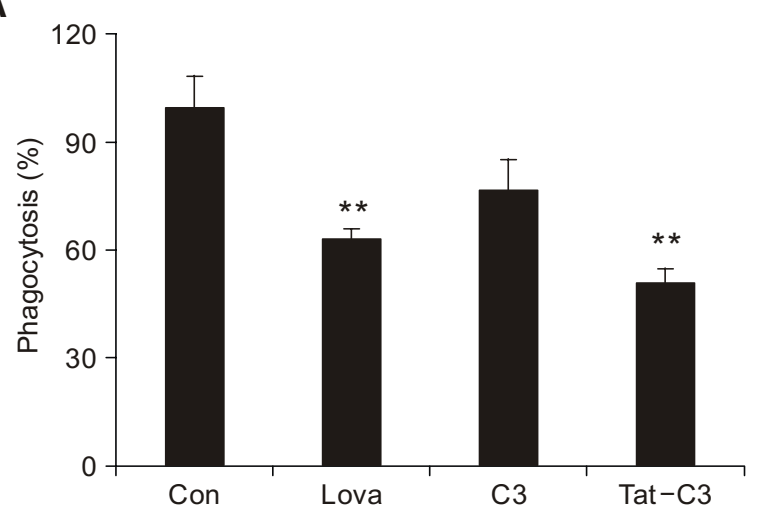

B

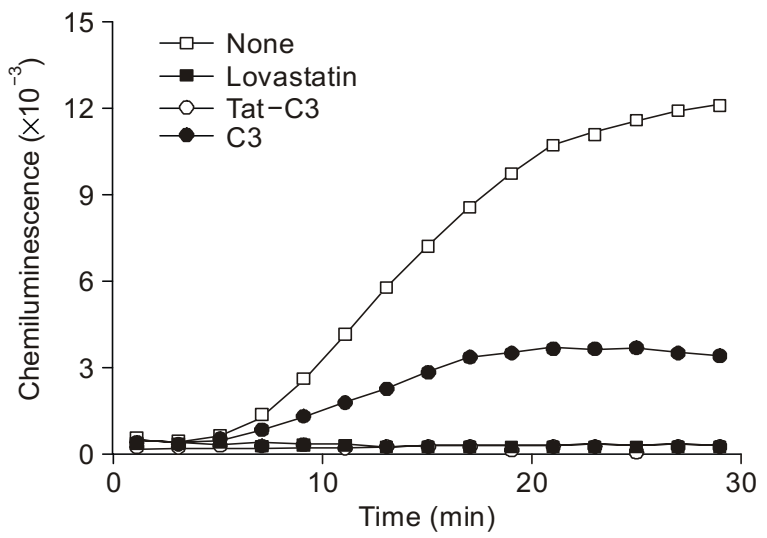

Figure 1. Involvement of Rho in the superoxide formation during phagocytosis of SOZ particles in macrophages. J774 cells $\left(2 \times 10^{5}\right)$ were treated with $50 \mu \mathrm{M}$ lovastatin, $50 \mu \mathrm{g} / \mathrm{ml}$ of $\mathrm{C} 3,10 \mu \mathrm{g} / \mathrm{ml}$ Tat-C3 for $1 \mathrm{hr}$ at $37^{\circ} \mathrm{C}$. For the phagocytosis, the cells were incubated with $5 \times 10^{5}$ of FITC-conjugated zymosan particles previously opsonized in fresh serum for $30 \mathrm{~min}$. The phagocytosis was assayed by measuring the intensity of fluorescence of FITC bound to zymosan by using a fluorescence spectrophotometer. The fluorescence of adherent FITC-zymosan on the surface of the cells was quenched by adding crystal violet to $10 \mu \mathrm{M}$ of final concentration. The values were means $\pm \mathrm{SE}\left(n=3,{ }^{* *} P<0.01\right)(\mathrm{A})$. For the measurement of intracellular superoxide, J774 cells $\left(2 \times 10^{3}\right)$ were resuspended in $1 \mathrm{ml}$ of KRG buffer containing $50 \mathrm{U} / \mathrm{ml} \mathrm{SOD,} 2000 \mathrm{U} / \mathrm{ml}$ catalase and $50 \mu \mathrm{M}$ luminol. The reaction of superoxide formation was started by addition of opsonized zymosan particles $\left(2 \times 10^{4}\right)$, and the subsequent chemiluminiscence was measured by using Luminometer. $50 \mu \mathrm{g} / \mathrm{ml}$ of C3 $(\mathbf{O}), 10 \mu \mathrm{g} / \mathrm{ml}$ purified Tat-C3 exoenzyme ( $\bigcirc), 50 \mu \mathrm{M}$ lovastatin ( $\mathbf{\square})$, and none $(\square)$ were pretreated to the J774 cells for 30 min at $37^{\circ} \mathrm{C}(\mathrm{B})$. 
GST-p $47^{\text {PHOX }}$ fusion protein in the cell lysate was purified on GSH-Sepharose. The purity and identity of the fusion protein were assayed by $10 \%$ SDSPAGE and immunoblotting. Kinase assay of recombinant GST-p47 $7^{\text {PHOX }}$ fusion protein was performed following Yammamori's method (Yammamori et al., 2000). Briefly, macrophages $\left(2 \times 10^{7}\right)$ in Hanks' balanced salt solution containing $0.5 \mathrm{mM} \mathrm{CaCl}_{2}$ and $1 \mathrm{mM} \mathrm{MgCl} 2$ (HBSS+) were incubated for $5 \mathrm{~min}$ at $37^{\circ} \mathrm{C}$ and then stimulated with $1 \mathrm{mg} / \mathrm{ml}$ of SOZ for 15 $\min$ at $37^{\circ} \mathrm{C}$. The reaction was stopped by centrifugation and the cells were suspended in $50 \mu \mathrm{l}$ of ice-cold lysis buffer (20 mM Hepes, pH 7.7, 75 mM $\mathrm{NaCl}, 2.5 \mathrm{mM} \mathrm{MgCl}_{2}, 0.1 \mathrm{mM}$ EDTA, $0.05 \%$ Triton $\mathrm{X}-100,0.5 \mathrm{mM}$ DTT, $20 \mathrm{mM}$ L-glycerophosphate, 0.1 $\mathrm{mM} \mathrm{Na} \mathrm{VO}_{4}, 2 \mu \mathrm{g} / \mathrm{ml}$ of leupeptin, and $100 \mu \mathrm{g} / \mathrm{ml}$ PMSF). Cells were then lysed by sonication and the extracts were obtained by centrifugation. The extracts were mixed with $75 \mu \mathrm{l}$ of GSH-sepharose suspension to which $15 \mu \mathrm{g}$ of GST-p47 $7^{\text {PHOX }}$ was bound, and rotated for $3 \mathrm{~h}$ at $4^{\circ} \mathrm{C}$. After the sepharose beads were washed four times with Hepes binding buffer (20 mM Hepes, pH 7.7, $50 \mathrm{mM} \mathrm{NaCl}, 2.5 \mathrm{mM}$ $\mathrm{MgCl}_{2}, 0.1 \mathrm{mM}$ EDTA, and $0.05 \%$ Triton $\mathrm{X}-100$ ), they were resuspended in $30 \mu \mathrm{l}$ of kinase buffer $(20 \mathrm{mM}$ Hepes, pH 7.6, $20 \mathrm{mM} \mathrm{MgCl} 2,20 \mathrm{mM}$ L-glycerophosphate, $0.1 \mathrm{mM} \mathrm{Na}_{3} \mathrm{VO}_{4}$, and $2 \mathrm{mM}$ DTT) containing $20 \mu \mathrm{M}$ ATP and $10 \mu \mathrm{Ci}$ of $\left[\gamma^{32} \mathrm{P}\right] \mathrm{ATP}$. After incubation for $20 \mathrm{~min}$ at $30^{\circ} \mathrm{C}$, the beads were washed with Hepes binding buffer for stopping kinase reaction. Laemmli sample buffer was added to the beads, which were boiled to separate GST$\mathrm{p} 47^{\mathrm{PHOX}}$ from them. The separated GST-p47 $7^{\mathrm{PHOX}}$ was subjected to $10 \%$ SDS-PAGE. After drying the gel, autoradiography of phosphorylated GST-p47 ${ }^{\text {PHOX }}$ was performed.

\section{Results}

Intracellular formation of superoxide during phagocytosis of SOZ reached maximal extent level in 30 min when it was measured with luminol (Figure 1B). However, the formation of extracellular superoxide, which was measured with isoluminol, was delayed in comparison with that of intracellular superoxide (data not shown). To attempt to confirm whether Rho is involved in the superoxide formation, the effect of the inhibition of Rho activity of $\mathrm{J} 774$ macrophages on superoxide formation was examined. First the macrophages were treated with C3 that specifically inhibit Rho, and with Tat-C3 that was readily transduced into cells resulting in specific inhibition of Rho. Both C3 and Tat-C3 inhibited superoxide formation in macrophages induced by SOZ particles, but Tat-C3 much more efficiently inhibited it (Figure 1A) since C3 may have a limitation for the translocation into the cells (Park et al., 2003). Tat-peptide itself did not inhibit the superoxide formation (data not

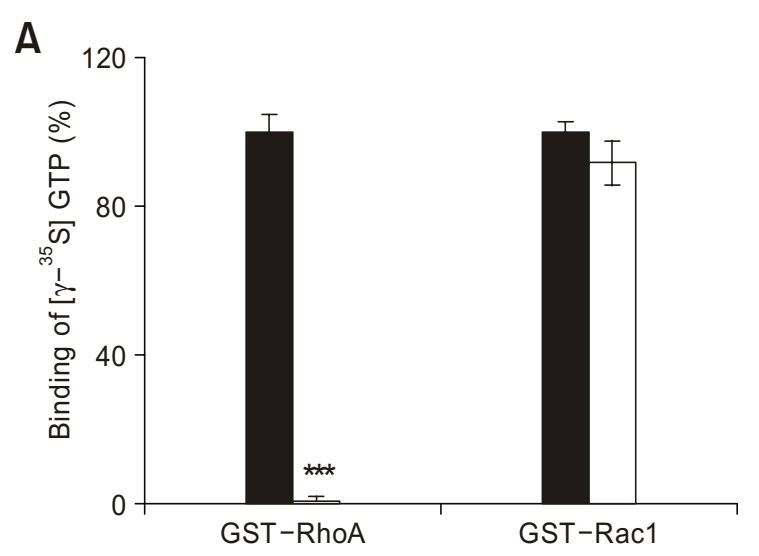

B

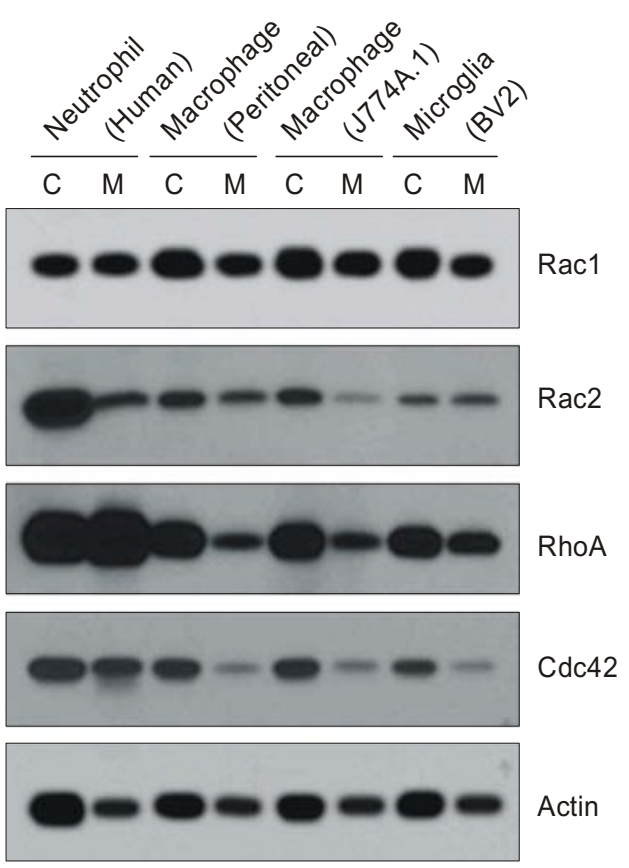

Figure 2. Inhibition of RhoA by Tat-C3 and expression of Rho GTPases in the leukocytes cell types. For ADP-ribosylation of GST-fusion proteins, $10 \mu \mathrm{g} / \mathrm{ml}$ of Tat-C3 ( $\square$ ) or none $(\mathbf{\square}), 3 \mu \mathrm{M} \mathrm{NAD}^{+}, 6 \mu \mathrm{M}$ GDP, 1 $\mu \mathrm{g} / \mathrm{ml}$ GST-RhoA or GST-Rac1 in $50 \mu \mathrm{l}$ buffer were premixed on ice. ADP-ribosylation reaction was started with the addition of the GST-RhoA protein or -Rac1 and incubated for $1 \mathrm{~h}$ at $37^{\circ} \mathrm{C}$. For the binding of GTP, GST-RhoA and -Rac1 were incubated with $0.1 \mu \mathrm{M}\left[\gamma^{35} \mathrm{~S}\right]-$ GTP or in $50 \mu \mathrm{l}$ of GTP-binding buffer at $30^{\circ} \mathrm{C}$ for $10 \mathrm{~min}$. The GTP-binding activities were assayed by membrane filtering methods. The values were means \pm SE $\left(n=3,{ }^{* * *} P<0.01\right)$ (A). Immunoblot was performed with extracts prepared from freshly isolated neutrophils (human), macrophage (peritoneal or J774A.1 cell line), and microglia (BV2 cell line), by using anti-Rac1, anti-Rac2, anti-RhoA, anti-Cdc42 or anti-Actin antibody, as indicated (B). 
shown). Moreover, lovastatin that inhibits the synthesis of prenyl group also inhibited superoxide formation. It has been known that RhoA GTPase has a geranygeranyl group at Cys residue of C-terminus (Glomst and Farnsworth, 1994). These results indicate that Rho is essential in the superoxide formation induced by SOZ particles.

To eliminate the possibility that Tat-C3 inhibits Rac1, the GTP-binding activity of RhoA and Rac1 was assayed with or without pretratment of Tat-C3. Tat-C3 completely inhibited GTP-binding to GSTRhoA, whereas it did not abrogate GTP-binding to Rac1, suggesting that Tat-C3 specifically inhibits RhoA activity. In addition to the evidence that Tat-C3 did not inhibit Rac1, we compared the relative amounts of Rac1 and Rac2 in several cells and cell lines. Apparent Rac1 amount seems to be higher in $\mathrm{J} 774$ cells than in neutrophils, whereas Rac2, RhoA and Cdc42 seem to be higher in neutrophils than in J774 cells, peritoneal macrophages, and BV2 cells (Figure 2).

To confirm directly whether Rho is involved in the formation of superoxide in vitro, macrophage cell lysates were incubated with the purified recombinant
GST-RhoA in the presence of GDP or GTP. It was found that GST-RhoA stimulated the superoxide formation in the concentration-dependent manner in the presence of GTP, whereas it did not in the presence of GDP (data not shown). In addition, RhoA was translocated to the membranes during phagocytosis of SOZ particles (Figure $3 \mathrm{~A}$ ), suggesting that RhoA may be involved in the superoxide formation and be activated during phagocytosis of SOZ particles. As controls, localization of RalA and caveolin on cell membranes was not changed in response to phagocytosis of SOZ or treatments of Tat-C3 in contrast to RhoA (Figure 3B). Both SOZ and IOZ activated RhoA, Rac1, and Rac2, and the time courses of their activation were a little different: active RhoA and Rac1 were continuously increased, whereas Rac2 was trended to be activated in early time, and sustained (Figure $3 \mathrm{C}$ ). We assessed the morphology of macrophages by scanning electric microscope to test the relevance of RhoA to an interaction of macrophages with SOZ particles. SOZ induced well-developed dorsal membrane ruffles, whereas Tat-C3 blocked it and induced spreading of cells resulting in attachment of peripheral mem-
A

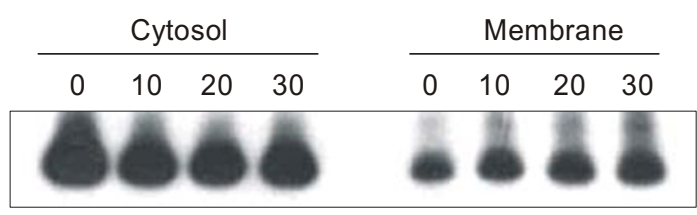

C
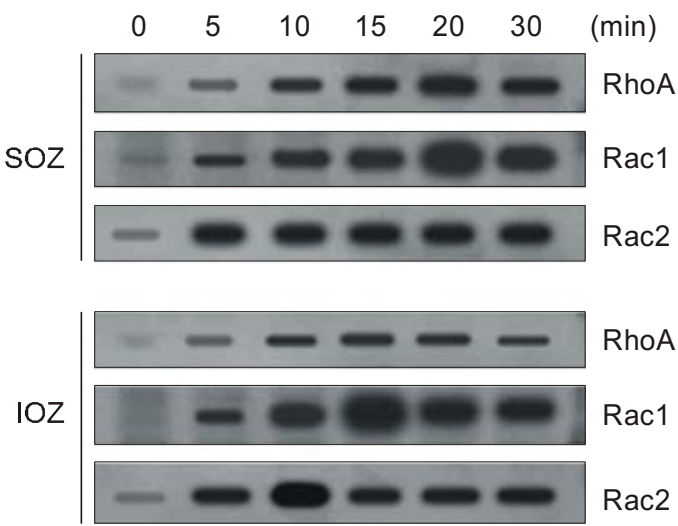

B
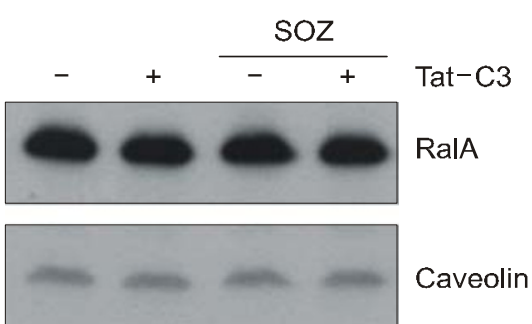

D

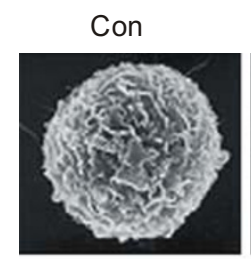

SOZ
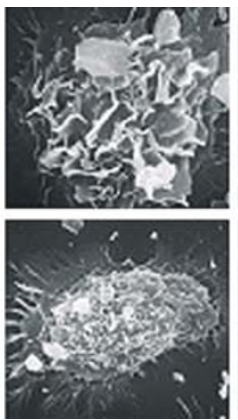

$10 Z$
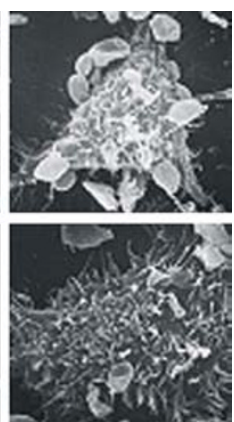

Figure 3. Activation of Rho GTPases during phagocytosis of $\mathrm{SOZ}$ or IOZ particles in macrophages. To measure the translocation of RhoA, the cells of phagocytosis were ruptured by using a sonicator, and the membrane and cytosolic fractions were separated using ultracentrifugation at $100,000 \times g$, $4^{\circ} \mathrm{C}$ for $30 \mathrm{~min}$. RhoA of the membranes and the cytosol were detected by Western blot by using anti-RhoA (A). RalA and caveolin of membrane fraction were measured by using anti-RalA and anti-caveolin antibodies after phagocytosis of SOZ for 30 min in macrophages pretreated with or without 10 $\mu \mathrm{g} / \mathrm{ml}$ Tat-C3 for $30 \mathrm{~min}(\mathrm{~B})$. Macrophages $\left(2 \times 10^{5} \mathrm{cells}\right)$ were challenged with SOZ or IOZ particles $\left(5 \times 10^{5}\right)$ for indicated times. Cells were harvested and lysed with a buffer containing 1\% Triton X-100. Activated Rho GTPases levels were detected by GST pull down assay and Western blot (C). SEM picture of microphages were challenged with SOZ or IOZ. $10 \mu \mathrm{g} / \mathrm{ml}$ Tat-C3 were pretreated to the J774A.1 cells for $30 \mathrm{~min}$ (D). 
A

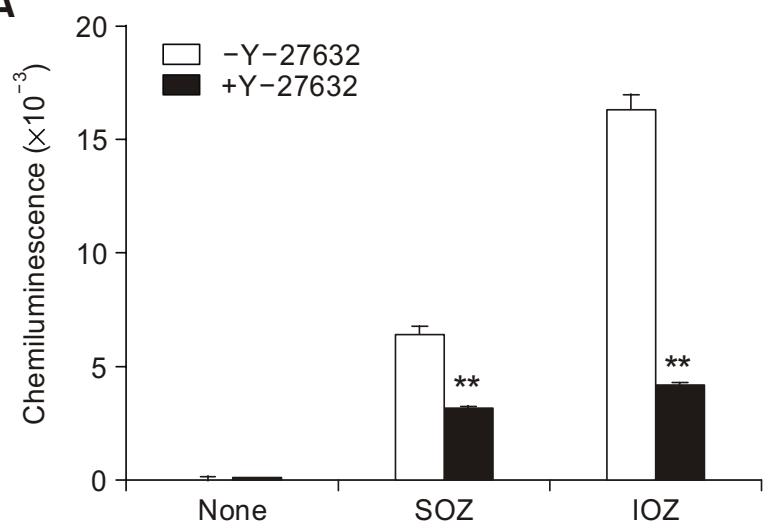

C

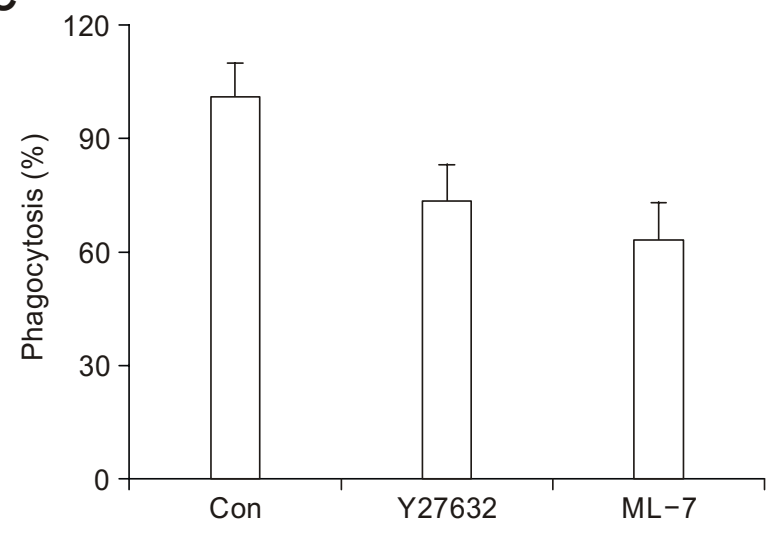

branes to substratum. On the other hand, IOZ did not induce membrane ruffles, and Tat-C3 induced more number of membrane protrusions (Figure 3D).

Next, we tried to reveal the downstream component to $\mathrm{Rho} A$ in the regulation of superoxide production. It was well known that RhoA-activated kinase (ROCK) is a typical effector protein of RhoA and Y-27632 is a specific inhibitor of ROCK. Y-27632 inhibited supeoxide formation, which was stimulated by both SOZ and IOZ, by about 50 and $75 \%$, respectively (Figure 4A). In addition, ML7, a specific inhibitor of myosin light chain kinase (MLCK) also inhibited superoxide formation, which was stimulated by both $\mathrm{SOZ}$ and $\mathrm{IOZ}$ particles, by about $85 \%$ (Figure 4B). Both ROCK and MLCK phosphorylate myosin light chain, leading to actomyosin assembly and contraction of cells. Thus we assessed effects of Y-27632 and ML-7 on phagocytosis to reveal the correlation of phagocytosis with superoxide production. Y-27632 and ML-7 inhibited phagocytosis of SOZ by about 30 and $35 \%$, respectively. This suggests that the reduction of superoxide by Y-27632 and ML-7 is partially dependent on the reduction of phagocytosis. ROCK and MLCK may be also involved in direct regulation of superoxide



Figure 4. Rho-dependent kinase (ROCK) and myosin light chain kinase (MLCK) is involved in superoxide formatiom. J774 cells $\left(2 \times 10^{3}\right)$ were pretreated with $30 \mu \mathrm{M}$ Y27632 (A) and $30 \mu \mathrm{M} \mathrm{ML-7} \mathrm{(B)} \mathrm{for} 30 \mathrm{~min}$. Macrophages were challenged with $\mathrm{SOZ}$ or $\mathrm{IOZ}$ for $30 \mathrm{~min}$, and then phagocytosis $(C)$ and Intracellular superoxide was measured as described in Figure 1. The values were means $\pm \operatorname{SE}\left(n=3,{ }^{* *} P<0.01\right)$.

generation in that the inhibition extent of superoxide production by the inhibitors was greater than inhibition of phagocytosis.

Thus we attempted to elucidate how Rho is implicated with the superoxide formation during phagocytosis. PMA [an activator of protein kinase $\mathrm{C}$ (PKC)] stimulated the phagocytosis and superoxide formation, whereas PD98059 [an inhibitor of MAP kinase kinase (MEK)], SB203580 [an inhibitor of p38 mitogen-activated protein kinase (MAPK)], and LY294002 [an inhibitor of phosphatidyl inositol-3 kinase (PI3K)] significantly inhibited the phagocytosis (Figure 5A). Additionally, the superoxide formation was seriously inhibited at the same concentration of inhibitors as the phagocytosis experiments were performed (Figure 5B), which is in accord with previous report (Yamamori et al., 2000). These indicate that PKC, extracellular signaling-regulated kinase (ERK1/2), PI3K, and p38 MAPK are relevant to the superoxide formation during phagocytosis. Thus, we attempted to elucidate which MAPK among ERK1/2, p38 MAPK, and c-Jun N-terminal kinase (JNK) was critical for the superoxide formation concerning the linkage of Rho to these intermediate molecules. It was found that Tat-C3 
A

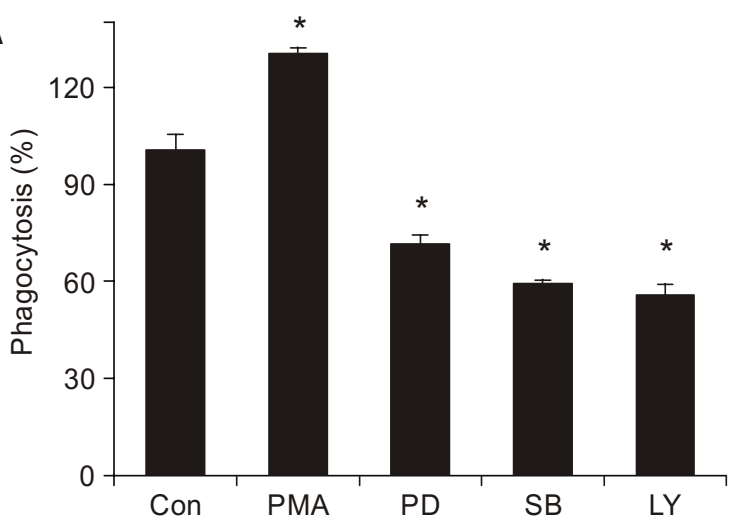

C

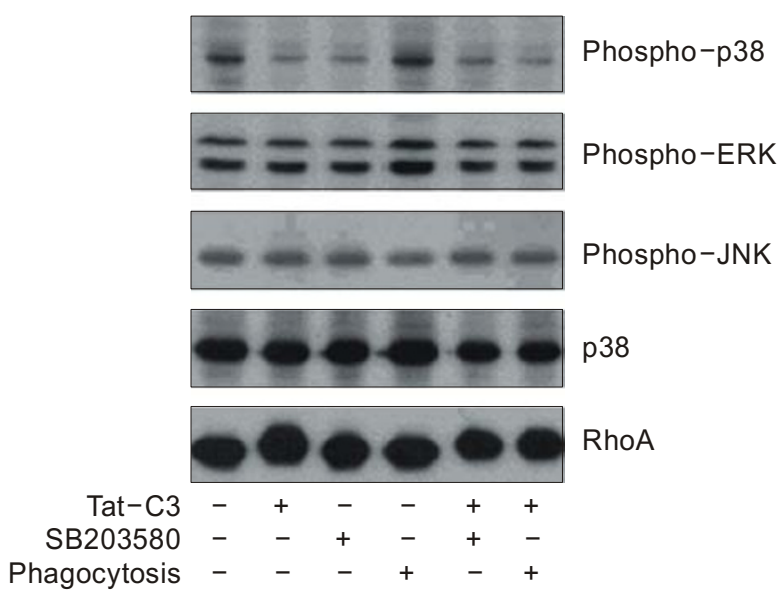

B

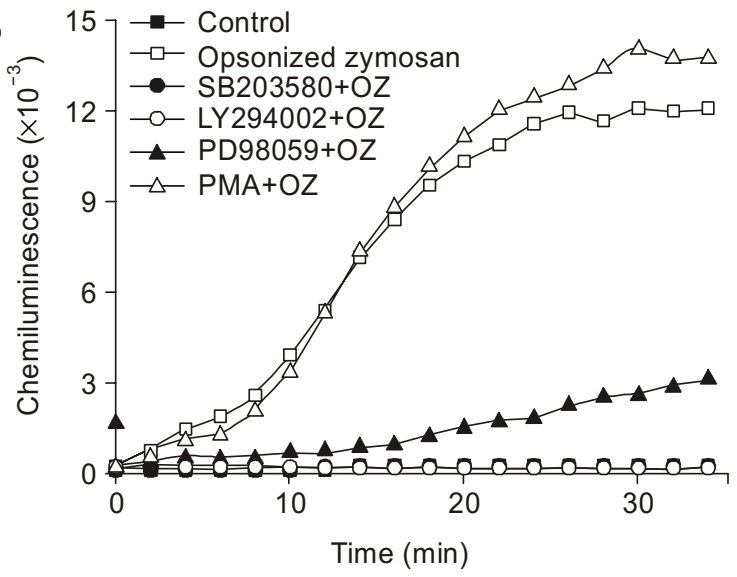

D

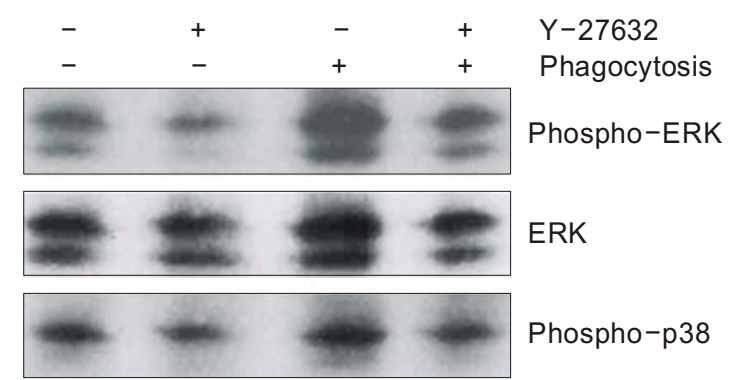

Figure 5. Implication of p38 MAPK and ERK1/2 to superoxide formation induced by RhoA. J774A.1 cells were pretreated with $10 \mathrm{nM}$ PMA, $50 \mu \mathrm{M}$ PD98059, $30 \mu \mathrm{M}$ SB203580, and $50 \mu \mathrm{M}$ LY294002 for $30 \mathrm{~min}$, and phagocytosis was performed. The phagocytosis of SOZ particles was measured as in Figure 1. The values were means $\pm \mathrm{SE}\left(n=3,{ }^{*} P<0.05\right)(\mathrm{A})$. The superoxide formation during phagocytosis was measured from the cells pretreated with the same concentration as in $(A)$ of PMA $(\Delta)$, PD98059 $(\mathbf{\Delta})$, SB203580 $(\mathbf{O})$, LY294002 $(\bigcirc)$, and none $(\boldsymbol{\square})(B)$. J774 cells were pretreated with $10 \mu \mathrm{g} / \mathrm{ml}$ of Tat-C3 exoenzyme or $30 \mu \mathrm{M} \mathrm{SB} 203580$ for $30 \mathrm{~min}$, and then phagocytosis was performed. The cell lysates (20 $\mu \mathrm{g}$ protein) were run on SDS-PAGE and Western blots were performed by using anti-p38, -phospho-p38, -phospho-ERK, -phospho-JNK, and -RhoA antibodies. It was observed that Tat-C3 exoenzyme retarded the mobility of RhoA on SDS-PAGE (C). J774 cells were pretreated with $50 \mu \mathrm{M}$ Y-27632 for $30 \mathrm{~min}$, and then phagocytosis was performed. The cell lysates $(20 \mu \mathrm{g}$ protein) were run on SDS-PAGE and Western blots were performed by using, anti-phospho-ERK, -ERK1/2, -phospho-p38 MAPK antibodies (D).

strongly inhibited the phosphorylation of p38 MAPK, and slightly that of ERK1/2, but not JNK (Figure 5C), suggesting that p38 MAPK may be mainly involved in the superoxide formation mediated through Rho during phagocytosis of SOZ particles. It was found that the mobility of RhoA from the cells treated with Tat-C3 was retarded on SDS-PAGE, indicating that Tat-C3 modified the RhoA (Figure $5 \mathrm{C}$ ), whereas Tat-C3 did not change mobility of RalA and caveolin as controls (Figure 3B). In addition, Y-27632 blocked the activation of both ERK1/2 and p38 MARK, indicating that ROCK is upstream to ERK1/2 and p38 MARP (Figure 5D).

Since p38 MAPK and ERK have been reported to regulate superoxide formation by phosphorylating p47 $7^{\text {PHOX }}$, a cytosolic component of NADPH oxidase
(El Benna et al., 1996), we attempted to reveal a hierarchy of RhoA and other kinases tested in the superoxide formation mediated through RhoA. SOZ induced translocation of RhoA from cytosol to membrane, suggesting that $\mathrm{SOZ}$ activates RhoA. Consistently, Tat-C3 blocked the translocation of RhoA, whereas SB203580 and PD98059 and LY294002did not significantly block it (Figure 6A), indicating that RhoA may be an upstream component of p38MAPK, ERK1/2, and PI3K. However, Tat-C3 did not affect the translocation of Rac1 (Figure 6B). Then the phosphorylation of $\mathrm{p} 47^{\mathrm{PHOX}}$ was assayed by incubating GST-p47 ${ }^{\text {PHOX }},\left[\gamma_{-}^{32}\right.$ P]ATP, and the lysates from the J774 cells performing phagocytosis. The lysates from the cells excuting phagocytosis of $\mathrm{SOZ}$ stimulated the phosphorylation of $\mathrm{p} 47^{\mathrm{PHOX}}$, whereas 

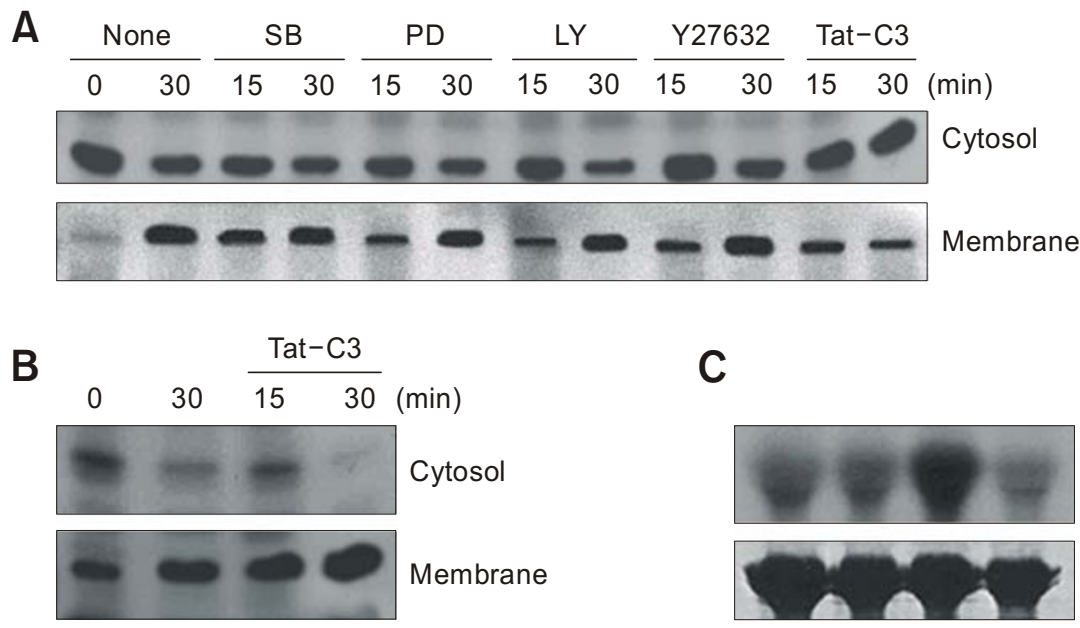

C

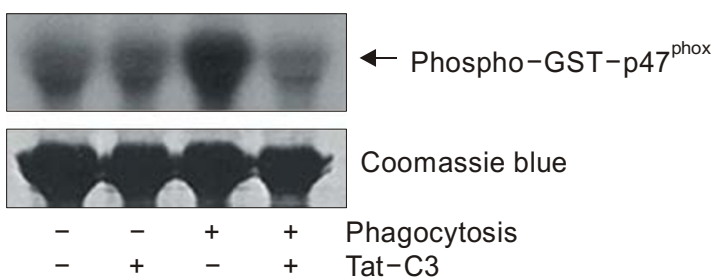

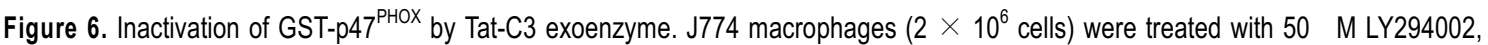
$50 \mu \mathrm{M}$ PD98059, $30 \mu \mathrm{M}$ SB203580, and $10 \mu \mathrm{g} / \mathrm{ml}$ Tat-C3 exoenzyme for $30 \mathrm{~min}$ at $37^{\circ} \mathrm{C}$. The cells were harvested and lysed with a sonication in $50 \mu \mathrm{l}$ buffer. The cell membranes were harvested and the membranes were resuspended in $50 \mu \mathrm{l}$ buffer. Both the membrane and the supernatant solution were run on 14\% SDS-PAGE, and Western blot was performed by using anti-RhoA (A) and anti-Rac1 antibodies $(B)$. Macrophages $\left(2 \times 10^{6}\right.$ cells) were stimulated with or without SOZ $\left(5 \times 10^{6}\right)$ after cells were treated with or without $10 \mu \mathrm{g} / \mathrm{ml}$ Tat-C3. The cells were then ruptured by sonication, and the cell extracts were mixed with GSH-Sepharose suspension to which GST-p47 ${ }^{\text {PHOX }}$ was bound. The mixture was rotated for binding of GST-p47 $7^{\text {PHOX }}$ and GSH-beads, and the washed beads were in $30 \mu \mathrm{l}$ of kinase buffer containing $10 \mu \mathrm{Ci}$ of $\left[\gamma^{32}\right.$ P]ATP. The phosphorylated GST-p47 ${ }^{\text {PHOX }}$ was analyzed on $10 \%$ SDS-PAGE and autoradiography $(\mathrm{C})$.

the lysates from the cells pretreated with Tat-C3 heavily inhibited the phosphorylation p4 $7^{\mathrm{PHOX}}$ (Figure $6 C)$.

\section{Discussion}

\section{Rho is essential for the superoxide formation in macrophages}

Rho proteins are Ras-related GTP-binding proteins that have been shown to regulate a variety of cellular functions such as cytoskeleton organization, membrane trafficking, transcriptional activation, cell growth control, and development (Hall A, 1998). Although Rac has been known to be essential for the superoxide formation in macrophage during phagocytosis (Kleinberg et al., 1990), there was a report supporting a possibility that RhoA exerts regulatory function in superoxide formation through NADPH oxidase during phagocytosis of $\mathrm{SOZ}$ (Kim et al., 2004). In this study, we attempted to reveal the downstream components of RhoA in signaling of superoxide generation, and observed that ROCK, MLCK, ERK1/2, p38MAPK were relevant to this process.

For this purpose, we used Tat peptide fused $\mathrm{C} 3$ exoenzyme (Tat-C3) to block RhoA. There was another possibility that Tat-C3 might also inhibit the
Rac (Kreck et al., 1994), which has been reported to be a stimulatory factor for NADPH oxidase. To exclude this possibility, we compared the GTPbinding activities of RhoA and Rac1 when they were treated with Tat-C3 in the presence of $\mathrm{NAD}^{+}$in vitro, and found that Tat-C3 completely abolished the GTP-binding activity of only RhoA, but not that of Rac1 (Figure 2).

We found that Tat-C3, which inhibits specifically the activity of Rho, moderately inhibited the phagocytosis, but extensively suppressed the superoxide formation induced by sOZ particles (Figure 1). These results suggest that Rho is esentially required for superoxide formation in CR3-mediated process (Figure 1). This indicates that the inhibition of superoxide formation is not a consequence of the reduction of phagocytosis. Rho may regulate the superoxide formation at least partially independently of phagocytosis. However, it is also true that phagocytosis stimulates the superoxide formation in macrophages in that the stimulation of the receptors by $\mathrm{C} 3 \mathrm{bi}$ protein ligands alone in macrophages did not induce the oxidative burst to full extent (Kim et al., 2004).

Additionally, it was shown that GST-RhoA stimulated the formation superoxide in the cell lysates and GTP (data not shown) although the stimulation extent was not high probably because of using 
recombinant RhoA instead of prenylated RhoA. This suggests that RhoA may be in fact involved in the superoxide formation in vitro. However, it cannot be excluded to consider a possible role of RhoB and $C$ for the involvement in superoxide formation, because C3 was also found to modify and inhibit both Rho B and C (Chardin et al., 1989; Just et al., 1995).

Conversely, RhoA was activated by the stimulation of SOZ: RhoA was translocated from cytosol to membrane, GTP-bound form of RhoA was well as both Rac1 and Rac2 was increased (Figure 3C). Furthermore, SOZ heavily induced dorsal membrane ruffles that might enclose and engulf the particles into inside of the cells (Figure 3D) (Park, 2003).

Next, we clarify whether superoxide produced by SOZ could increase control phagocytosis, since it was reported that reactive oxygen species (ROS), perhaps $\mathrm{H}_{2} \mathrm{O}_{2}$, acts as an intracellular signal mediator for NGF-induced neuronal differentiation and that NGF-stimulated ROS production is regulated by Rac1 and a flavoprotein-binding protein similar to the phagocytic NADPH oxidase (Suzukawa et al., 2000). In macrophages, superoxide scavenger or generator did not change the phagocytosis (data not shown; Kim et al., 2004), suggesting that superoxide does not act as an intracellular signal mediator for the phagocytosis.

\section{Mechanism for the superoxide formation mediated through Rho in macrophages}

To get a clue how RhoA is implicated in the superoxide formation during phagocytosis in macrophages, we examined the effects of the reagents that activate or inhibit specific steps in signal pathways. PKC was involved in stimulation of phagocytosis and association of SOZ particles in accordance with a previous report (Yamamori et al., 2000). Moreover, we found that p38 MAPK, ERK1/2, and $\mathrm{PI} 3 \mathrm{~K}$ were slightly involved in the phagocytosis process. In addition, the stimulation of PKC increased the superoxide formation, whereas the inhibition of ERK1/2 significantly reduced the superoxide formation, furthermore the inhibition of p38 MAPK and PI3K almost abolished it (Figure 5B). It could be suggested that p38 MAPK and PI3K are essential for the superoxide formation, and that phagocytosis and superoxide formation are performed through different signal-pathways. Furthermore, Tat-C3 heavily inhibited the phosphorylation of p38 MAPK and slightly that of ERK1/2, suggesting that p38 MAPK and ERK1/2 may be involved in the formation of superoxide mediated though Rho (Figure 5C).

It was found that the onset of respiratory burst during phagocytosis was linked to the phsophor- ylation of $\mathrm{p} 47^{\mathrm{PHOX}}$ and its trnaslocation to the phagosome (DeLeo et al., 1999). p38 MAPK was known to activate $\mathrm{p} 47^{\mathrm{PHOX}}$ by phosphorylation (Yamamori et al., 2000; Herlaar and Brown, 1999). The lysates from the cells executing phagocytosis of SOZ stimulated the phosphorylation of GST$\mathrm{p} 47^{\mathrm{PHOX}}$, and those from the cells treated by Tat-C3 blocked phosphorylation of GST-p47 $7^{\text {PHOX }}$ (Figure $6 \mathrm{C})$, suggesting that Rho is related to the phosphorylation of $\mathrm{p} 47^{\mathrm{PHOX}}$. The inhibition of $\mathrm{p} 47^{\mathrm{PHOX}}$ through Tat-C3 appears to subsequently diminish the superoxide formation. Consequently, the sequence of 'Rho $\rightarrow$ ROCK $\rightarrow$ p38 MAPK $\rightarrow$ ERK1/2 $\left(\rightarrow\right.$ ?) $\mathrm{p} 47^{\mathrm{PHOX}} \rightarrow$ superoxide' can be considered as a signal pathway of the activation of superoxide formation.

Cytoskeleton reorganization may be involved in the superoxide formation. Inhibition of superoxide formation by cytochalasin $D$ (data not shown) suggests a necessary role of cytoskeleton in the signaling pathway that activates the oxidase (Serrander et al., 1999). RhoA has been known as an activator for ROCK, which phosphorylates myosin light chain (MLC) phosphatase to be inactive (Kawano et al., 2000), resulting in the formation of stress fiber. ML7, an inhibitor of MLCK, inhibited that superoxide formation and phagocytosis in our system (Figure 4) and in other laboratories (Kimura et al., 1996; Mansfield et al., 2000), suggesting that cytoskeleton reorganization is important for the superoxide formation, although it has to be also considered that the inhibition of superoxide formation by ML7 may arise from the reduction of the phagocytosis. Moreover, ML7 was known to reduce the phosphorylation and the translocation of $\mathrm{p} 47^{\mathrm{PHOX}}$ to the membranes (Heyworth et al., 1995).

RhoA has been also known to be an activator of phospholipase D (PLD) (Malcolm et al., 1994). Thus, the possibility of the formation of phosphatidic acid (PA) formation in the membranes could be a regulator of superoxide formation, for example, a regulator of translocation of NADPH oxidase. It was reported that Rac/RhoGDI complex can be disrupted in the presence of various lipids like arachidonic acid, PA, and phosphatidylinositol (Chuang et al., 1993). We found that the addition of exogenous PLD to the macrophages induced the enhancement of the superoxide formation (results not shown), suggesting that PLD activity is required for the superoxide formation. It has been shown that $\mathrm{p} 22^{\mathrm{PHOX}}$ can be phosphorylated through PLD, suggesting that PLD activity is required for the superoxide formation (Regier et al., 2000). Moreover, the activation of PLD is tightly coupled to the phagocytosis of opsonized zymosan by human macrophages (Fallman et al., 1993; Kusner et al., 1996). 
Despite of such multiple events associated to superoxide formation, it remains to be studied in detail how Rho regulates the processes including the activations of p38 MAPK and ERK1/2, and the phosphorylation of $\mathrm{p} 47^{\mathrm{PHOX}}$.

\section{Acknowledgement}

This study was supported by Grant A020007 from the Korea Health 21 R\&D Project, Ministry of Health and Welfare, Republic of Korea. Anti-p47 $7^{\text {PHOX }}$ anti-

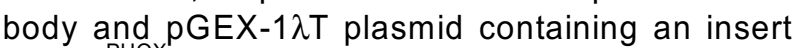
of $447^{\text {PHOX }}$ cDNA were kindly sent from Dr. J. W. Park at Kyoungbuk National University. We express our thanks to Dr. Gary M. Bokoch at The Scripps Research Institute for supplying anti-p4 $7^{\text {PHOX }}$ antibody.

\section{References}

Allen LAH, Aderem A. Molecular definition of distinct cytoskeletal structures involved in complement- and Fc receptor-mediated phagocytosis in macrophages. J Exp Med 1996;184:627-37

Aktories K, Braun U, Rosener S, Just I, Hall A. The rho gene product expressed in $\mathrm{E}$. coli is a substrate of botulinum ADP-ribosyltransferase C3. Biochem Biophys Res Commun 1989;158:209-13

Babior B. NADPH oxidase: an update. Blood 1999;93:146476

Bokoch G. Regulation of the human neutrophil NADPH oxidase by the Rac GTP-binding proteins. Curr Opi Cell Biol 1994;6:212-8

Bokoch GM, Quilliam LA, Bohl BP, Jesaitis AJ, Quinn MT. Inhibition of Rap1A binding to cytochrome b558 of NADPH oxidase by phosphorylation of Rap1A. Science 1991;254: 1794-6

Brown EJ. Phagocytosis. BioEssay 1995;17:109-17

Caron E, Hall A. Identification of two distinct mechanisms of phagocytosis controlled by different Rho GTPases Science 1998;282:1717-21

Chardin P, Boquet P, Madaule P, Popoff MR, Rubin EJ, Gill $D M$. The mammalian $G$ protein rhoC is ADP-ribosylated by Clostridium botulinum exoenzyme $\mathrm{C} 3$ and affects actin microfilaments in Vero cells. EMBO J 1998;8:1087-92

Chimini G, Chavrier P. Function of Rho family proteins in actin dynamics during phagocytosis and engulfment. Nature Cell Biol 2000;2:E191-6

Chuang TH, Bohl BP, Bokoch GM. Biologically active lipids are regulators of Rac. GDI complexation. J Biol Chem 1993;268:26206-11

Cox D, Chang P, Zhang Q, Reddy PG, Bokoch GM, Greenberg S. Requirements for both Rac1 and Cdc42 in membrane ruffling and phagocytosis in leukocytes. J Exp Med 1997;186:1487-94
Dahlgren C, Karlsson A. Respiratory burst in human neutrophils. J Immunol Med 1999;232:3-14

DeLeo F Allen LAH, Apicella M, Nauseef WM. NADPH oxidase activation and assembly during phagocytosis. J Immunol 1999;163:6732-40

El Benna J, Han J, Park JW, Schimid E, Ulevitch RJ, Babior BM. Activation of p38 in stimulated human neutrophils: phosphorylation of the oxidase component p47phox by p38 and ERK but not by JNK. Arch Biochem Biophys 1996;334: $395-400$

Fallman M, Andersson R, Andersson T. Signaling properties of CR3 (CD11b/CD18) and CR1 (CD35) in relation to phagocytosis of complement-opsonized particles. J Immunol 1993;151:330-8

Gelfand JA, Fauci AS, Green I, Frank MM. A simple method for the determination of complement receptor-bearing mononuclear cells. J Immunol 1976;116:595-9

Glomset JA, Farnsworth CC. Role of protein modification reactions in programming interactions between Ras-related GTPases and cell membranes. Annu Rev Cell Biol 1994; 10:181-205

Hackam DJ, Rotstein OD, Schreiber A, Zhang WJ, Grinstein $\mathrm{S}$. Rho is required for the initiation of calcium signaling and phagocytosis by Fcgamma receptors in macrophages. J Exp Med 1997;186:955-66

Hall A. Rho GTPases and the actin cytoskeleton. Science 1998;279:509-14

Hed J, Hallden G, Johansson SG, Laesson P. The use of fluorescence quenching in flow cytofluorometry to measure the attachment and ingestion phases in phagocytosis in peripheral blood without prior cell separation. J Immunol Methods 1987;101:119-25

Herlaar E, Brown Z. p38 MAPK signalling cascades in inflammatory disease. Mol Med Today 1999;5:439-47

Heyworth PG, Curnutte JT, Nauseef WM, Volpp BD, Pearson DW, Rosen H, Clark RA. Neutrophil nicotinamide adenine dinucleotide phosphate oxidase assembly. Translocation of p47-phox and p67-phox requires interaction between p47phox and cytochrome b558. J Clin Invest 1991;87:352-6

Heyworth PG, Erickson RW, Ding J, Curnutte JT, Badwey JA. Naphthalenesulphonamides block neutrophil superoxide production by intact cells and in a cell-free system: is myosin light chain kinase responsible for these effects? Biochem J 1995;311:81-7

Hippenstiel S, Kratz T, Krüll M, Seybold J, Eichel-Streiber C, Suttorp N. Rho protein inhibition blocks protein kinase $C$ translocation and activation. Biochem Biophys Res Comm 1998;245:830-4

Just I, Selzer J, Jung M , van Damme J, Vandekerckhove J, Aktories K. Rho-ADP-ribosylating exoenzyme from Bacillus cereus. Purification, characterization, and identification of the NAD-binding site. Biochemistry 1995;34:334-40

Kawano Y, Fukata Y, Oshiro N, Amano M, Nakamura T, Masaaki I. Matsumura F, Inagaki M, Kaibuchi K. Phosphorylation of myosin-binding subunit (MBS) of myosin 
phosphatase by Rho-kinase in vivo. J Cell Biol 1999; 147:1023-37

Kikuchi A, Yamashita T, Kawata M, Yamamoto K, lkeda K, Tanimoto T, Takai Y. Purification and characterization of a novel GTP-binding protein with a molecular weight of 24,000 from bovine brain membranes. J Biol Chem 1998;263:2897904

Kim C, Dinauer MC. Rac2 is an essential regulator of neutrophil nicotinamide adenine dinucleotide phosphate oxidase activation in response to specific signaling pathways. J Immunol 2001;166:1223-32

Kim JS, Kwon HY, Choi WH, Jeon CY, Kim JI, Kim J, Lee JY, Kim YS, Park JB. Phagocytosis of serum- and IgG-opsonized zymosan particles induces apoptosis through superoxide but not nitric oxide in macrophage J774.A1. Exp Mol Med 2003;35:211-21

Kim JS, Diebold BA, Kim JI, Kim J, Lee JY, Park JB. Rho is involved in superoxide formation during phagocytosis of opsonized zymosans. J Biol Chem 2004;279:21589-97

Kimura K, Ito M, Amano M, Chihara K, Fukata Y, Nakafuka M, Yamamori B, Feng J, Nakano T, Okawa K, Iwamatsu A, Kaibuchi K. Regulation of myosin phosphatase by Rho and Rho-associated kinase (Rho-kinase). Science 1996;273: $245-8$

Kreck ML, Uhlinger DJ, Tyagi SR, Inge KL, Lambeth JD. Participation of the small molecular weight GTP-binding protein Rac1 in cell-free activation and assembly of the respiratory burst oxidase. Inhibition by a carboxyl-terminal Rac peptide. J Biol Chem 1994;269:4161-8

Kleinberg ME, Malech HL, Rotrosen D. The phagocyte 47-kilodalton cytosolic oxidase protein is an early reactant in activation of the respiratory burst. J Biol Chem 1990;265: 15577-83

Knaus U, Heyworth P, Kinsella B, Curnutte J, Bokoch G. Purification and characterization of Rac 2. A cytosolic GTP-binding protein that regulates human neutrophil NADPH oxidase. J Biol Chem 1992;267:23575-82

Koo HY, Shin I, Lee ZW, Lee SH, Kim SH, Lee CH, Kang $\mathrm{HS}$, Ha KS. Roles of RhoA and phospholipase A2 in the elevation of intracellular $\mathrm{H} 2 \mathrm{O} 2$ by transforming growth factor-beta in Swiss 3T3 fibroblasts. Cell Signal 1999;11: $677-83$

Kusner JD, Hall CF, Schlesinger LS. Activation of phospholipase $\mathrm{D}$ is tightly coupled to the phagocytosis of Mycobacterium tuberculosis or opsonized zymosan by human macrophages. J Exp Med 1996;184:585-95

Kim JS, Diebold BA, Kim JI, Kim J, Lee JY, Park JB. Rho is involved in superoxide formation during phagocytosis of opsonized zymosans. J Biol Chem 2004;279:21589-97

Le Cabec V, Cols C, Maridonneau-Parini I. Nonopsonic phagocytosis of zymosan and Mycobacterium kansasii by CR3 (CD11b/CD18) involves distinct molecular determinants and is or is not coupled with NADPH oxidase activation. Infect Immu 2000;68:4736-45

Lee ZW, Kweon SM, Kim SJ, Kim JH, Cheong C, Park YM, $\mathrm{Ha} \mathrm{KS}$. The essential role of $\mathrm{H} 2 \mathrm{O} 2$ in the regulation of intracellular $\mathrm{Ca} 2+$ by epidermal growth factor in rat-2 fibroblasts. Cell Signal 2000;12:91-8

Löfgren R, Serrander L, Forsberg M, Wisson , Wasteson Stendahl O. CR3, FcgammaRIIA and FcgammaRIIIB induce activation of the respiratory burst in human neutrophils: the role of intracellular $\mathrm{Ca}(2+)$, phospholipase $\mathrm{D}$ and tyrosine phosphorylation. Biochim Biophys Acta 1999;1452:46-59

Malcolm KC, Ross AH, Qu RG, Symons M, Exton JH. Activation of rat liver phospholipase $D$ by the small GTP-binding protein RhoA. J Biol Chem 1994;269:25951-4

Mansfield PJ, Shayman JA, Boxer LA. Regulation of polymorphonuclear leukocyte phagocytosis by myosin light chain kinase after activation of mitogen-activated protein kinase. Blood 2000;95:2407-12

Massol P, Montocourrier P, Guillemot JC, Chavrier P. FC receptor-mediated phagocytosis requires CDC42 and Rac1. EMBO J 1998;17:6219-29

Mizuno T, Kaibuchi K, Ando S, Musha T, Hiraoka K, Takaishi K, Asada M, Nunoi H, Matsuda I, Takai Y. Regulation of the superoxide-generating NADPH oxidase by a small GTPbinding protein and its stimulatory and inhibitory GDP/GTP exchange proteins. J Biol Chem 1992;267:10215-8

Newman SL, Mikus LK. Deposition of C3b and iC3b onto particulate activators of the human complement system. Quantitation with monoclonal antibodies to human C3. J Exp Med 1985;161:1414-31

Park J, Kim JS, Jung KC, Lee HJ, Kim J, Lee JY, Park JB, Choi SY. Exoenzyme Tat-C3 inhibits association of zymosan particles, phagocytosis, adhesion, and complement binding in macrophage cells. Mol Cells 2003;16:216-23

Park JB. Phagocytosis induces superoxide formation and apoptosis in macrophages. Exp Mol Med 2003;35:325-35

Park JW, Babior BM. Activation of the leukocyte NADPH oxidase subunit p47phox by protein kinase C. A phosphorylation-dependent change in the conformation of the C-terminal end of p47phox. Biochemistry 1997a;36:7474-80

Park JW, Hoyal CR, El Benna J, Babior BM. Kinasedependent activation of the leukocyte NADPH oxidase in a cell-free system. Phosphorylation of membranes and p47 (PHOX) during oxidase activation. J Biol Chem 1997b; 272:11035-43

Quinn M, Evans T, Priscu L, Jesaitis A, Bokoch G. Translocation of Rac correlates with NADPH oxidase activation. Evidence for equimolar translocation of oxidase components. J Biol Chem 1993;268:20983-7

Quinn M, Parkos C, Walker L, Orkin S, Dinauer M, Jesaitis A. Association of a Ras-related protein with cytochrome b of human neutrophils. Nature 1989;342:198-200

Regier DS, Greene DG, Sergeant S, Jesaitis AJ, McPhail LC. Phosphorylation of p22phox is mediated by phospholipase D-dependent and -independent mechanisms. Correlation of NADPH oxidase activity and p22phox phosphorylation. J Biol Chem 2000;275:28406-12

Ren XD, Schwartz MA. Determination of GTP loading on Rho. Med Enzymol 2000;325:264-72 
Rotrosen D, Yeung CL, Katkin JP. Production of recombinant cytochrome b558 allows reconstitution of the phagocyte NADPH oxidase solely from recombinant proteins. J Biol Chem 1993;268:14256-60

Sathyamoorthy M, de Mendez I, Adams AG, Leto TL. p40 (phox) down-regulates NADPH oxidase activity through interactions with its SH3 domain. J Biol Chem 1997;272: 9141-6

Serrander L, Larsson J, Lundquist $\mathrm{H}$, Lindmark M, Fallman M, Dahgren C, Stendahl O. Particles binding beta (2)integrins mediate intracellular production of oxidative metabolites in human neutrophils independently of phagocytosis. Biochim Biophys Acta 1999;1452:133-44
Suzukawa K, Mimura K, Mitsushita J, Resau J, Hirose K, Crystal R, Kamata T. Nerve growth factor-induced neuronal differentiation requires generation of Rac1-regulated reactive oxygen species J Bio Chem 2000;275:13175-8

Wientjes FB, Panayotou G, Reeves E, Segal AW. Interactions between cytosolic components of the NADPH oxidase: p40phox interacts with both p67phox and p47phox. Biochem J 1996;317:919-24

Yamamori T, Inanami O, Nagahata H, Cui YD, Kuwabara M. Roles of p38 MAPK, PKC and PI3-K in the signaling pathways of NADPH oxidase activation and phagocytosis in bovine polymorphonuclear leukocytes. FEBS Lett 2000; 467:253-8 